\title{
Contextual complexity in business relationships within the input- output model - evidence of misbehaviour in grocery stores in Poland
}

\author{
Sławomir Smyczek \\ Department of Consumption Research, Faculty of Management, \\ University of Economics in Katowice, Katowice, Poland \\ Giuseppe Festa \\ Department of Economics and Statistics, University of Salerno, Fisciano, Italy \\ Matteo Rossi \\ Department of Law Economics Management and Quantitative Methods, \\ University of Sannio, Benevento, Italy and \\ Banking College, WSB University, Poznan, Poland, and \\ Alberto Mazzoleni \\ Department of Economics and Management, University of Brescia, Brescia, Italy
}

Complexity in business relations misbehaviour

3601

Received 8 December 2019 Revised 8 March 2020 25 March 2020

Accepted 25 March 2020

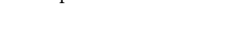

\begin{abstract}
Purpose - The emerging disintegrative processes of transitional economies are influencing companies' business models in terms of consumer behaviour, especially food markets, which offer usual, common and traditional consumer products. Beyond investigating potential consumer misbehaviour, a further aim of this study is the building of a theoretical-descriptive model for consumer misbehaviour in food markets, which could influence the contextual complexity in business relationships, as well as the management of raw materials, services acquisition and final product sales. The research applies the "input-output" model (Ferrero, 1968) to some specific marketing theories, adopting an interdisciplinary approach for understanding the relationships between consumer behaviour and a company's business model.

Design/methodology/approach - The research is both qualitative and quantitative in nature. In the first phase, the research was conducted among representatives of grocery stores using an exploratory approach; thus, an in-depth interview method was used. In the second phase, direct research among consumers was conducted using an online survey. After the verification of correctness, validity and reliability, a final 1,200-questionnaire dataset was analysed Findings - The most common consumer misbehaviour in food markets concerns the theft of foodstuff or the adoption of bad behaviour towards grocery stores employees. Market and store representatives have highlighted a large scale of pathological consumer misbehaviour, mostly due to psychological conditions at the individual (habits, lifestyle or personality) and collective (family or other social groups) levels. According to previous studies, consumer misbehaviour in food markets seems to be substantially affected by three factors: motivation, capacity and opportunity. These factors strongly impact the input-output model through which the company interacts with the context.

Originality/value - The three-factor model reveals advantages and applications, allowing for a simple explanation of consumer misbehaviour in food markets and stores. It can contribute to scientific theory development (especially theories related to consumer behaviour, customer relationship management, partnership marketing and supply chain
\end{abstract}

(C) Sławomir Smyczek, Giuseppe Festa, Matteo Rossi and Alberto Mazzoleni. Published by Emerald Publishing Limited. This article is published under the Creative Commons Attribution (CC BY 4.0) licence. Anyone may reproduce, distribute, translate and create derivative works of this article (for both commercial and non-commercial purposes), subject to full attribution to the original publication and authors. The full terms of this licence may be seen at http://creativecommons.org/licences/by/4.0/legalcode

This study is the result of the research project No. 2013/11/B/HS4/01470 - financed by National Science Center Poland.

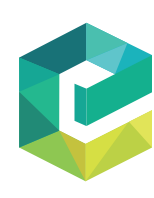

British Food Journal Vol. 122 No. 11,2020 pp. $3601-3621$ Emerald Publishing Limited DOI 10.1108/BFJ-12-2019-0894 
BFJ

122,11

management) and generate support for understanding complex relations among consumers, food producers, factories and food stores. In this direction, the management of knowledge about consumers and their behaviour is indispensable.

Keywords Consumer marketing, Consumer behaviour, Consumer misbehaviour, Food markets, Input-output model, Grocery stores, Poland

Paper type Research paper

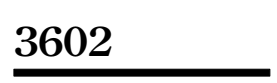

\section{Introduction}

The beginning of the 21st century has been characterized by the significant acceleration of various changes in the world, especially in transitional economies (Ho, 2020). It is worth noting that the current turbulent situation in the global market is systemic and spreads as a result of correlations that are typical of the globalization process; nonetheless, these changes have generated impactful conditions for consumer behaviour in food markets and may have both positive and negative effects on consumer behaviour.

In fact, the difficulties caused by the turbulent situation across the economy, mounted by constant transformation processes, often result in various social problems, including alcoholism, drug addiction, crime, mental addiction, suicide, disease, social care and education failure, family abuse and so forth. These emerging disintegrative processes are also reflected in consumer market behaviour, especially in food markets, which are increasingly offering products that satisfy not only the basic but also the sophisticated needs of every consumer.

To a certain extent, the rate of changes in transitional economies is higher than consumers' awareness of these ongoing changes and their ability to grasp these processes, which often leads to a phenomenon of consumers' negative adaptation to the new reality. In fact, consumers usually tend to adopt a more liberal approach towards phenomena that even recently were considered negative or pathological.

In fact, the environment acts as a complex system, activating numerous elements that are almost always interrelated: consumers represent one of these macro factors, as they influence the business surrounding the company and provide various inputs (Saita, 2005). External dynamism and turbulence due to the changeability of human needs may first impact product lines (Paolini, 1997) and then the company's business and strategy (Tiscini, 2014).

The relationship between the firm and its context could be understood more clearly by adopting the "input-output" model (Ferrero, 1968), in which the company is the centre of different exchanges with its environment (Bozzolan, 2001). In particular, the company receives several inputs (Giunta et al., 1993), such as consumers' needs, logistical factors, regulations and restrictions, which may represent positive or negative external forces. Then, inputs can be combined into the overall production process and final products and services can be obtained.

Along with the input-output model, the company is strongly influenced by the context/ environment (Ferrero, 1987) in which it exists, survives and develops (Giacosa, 2012), hindering its business and limiting its freedom and opportunities (Coda, 1988; Mazzoleni, 2012), and the enterprise may act as an active subject (Ferrero, 1967). Certainly, companies can influence human needs (Pollifroni, 2017), hopefully with respect to ethical values (Pavan and Modica, 2014 and 2016); however, all consumers can influence the company's strategy, communicating their needs.

Bearing in mind the above factors, it seems appropriate to investigate consumer misbehaviour in food markets, likely being the most important for consumption, with the aim of developing a theoretical-descriptive model of consumer misbehaviour in food markets and understanding the impact of such misbehaviour on the company's business. In fact, within the "input-output" model (Ferrero, 1968), consumer misbehaviour could influence the contextual complexity in different business relationships, such as the management of raw materials and service acquisition, production process handling and final product sales.

More specifically, our research model allows us to apply the "input-output" model (Ferrero, 1968) to some specific marketing theories by using an interdisciplinary approach to understand 
the relationships between consumer behaviour and the company's business model. Consequently, our framework focuses on both opportunities and restrictions-typically merged in the "inputoutput" model-due to consumer misbehaviour in the company's business model.

This research is both qualitative and quantitative in nature. From a structural point of view, the paper starts with an introduction, followed by theoretical background development and methodological approach presentation, and finishes with evidence emerging from a food market consumer misbehaviour analysis after an empirical investigation. Furthermore, this study is the result of research project No. 2013/11/B/HS4/01,470, financed by National Science Center Poland.

\section{Consumer misbehaviour-theoretical background}

Misbehaviour constitutes a very complex concept, not completely and perhaps straightforwardly defined in the specialist literature. Alongside economics, it is a subject of study for many scientific disciplines such as sociology, psychology and even biology: this condition, in turn, creates many methodological problems in examining consumer misbehaviour and its determinants.

In fact, initially, the term was used in medicine to define diseases of living organisms: soon, it became widely used in other human pathologies. In biology, for eg. the main focus was on the sources of misbehaviour (deviations), considered inherent in the nature of an individual (Siemaszko, 1993). Furthermore, the concept gained increased interest in psychology to describe and define the psychical disorders of an individual person. The concept was then investigated in social sciences as late as the end of the 19th century by Durkheim (2000), who differentiated between normal and pathological facts in society; however, in his definition of "normality," he did not underline the moral aspect but referred to normality as a common social circumstance.

Currently, misbehaviour is considered a negative social phenomenon that includes conditions such as the infringement of social norms, destructive behaviour gauged by social condemnation, occurring in large communities/groups or on a mass scale, and consequent necessity of preventive activities (Pospiszył, 2008). This phenomenon exists in various human groups and mainly concerns highly developed societies, where the systems of norms and values are unstable. Social changes such as misbehaviour cause are also demonstrated in the growing consumerism and mostly defined as a lifestyle predominantly oriented to negative situations about overconsumption, wastefulness, or even possession (Sztompka).

Bearing in mind consumers' strong orientation to obtain need satisfaction, sometimes, even at any cost, it seems relevant to approach the phenomenon of social misbehaviour in economic contexts and particularly to identify some misbehaviour in the consumer context (Fullerton and Punj, 1998; Vitell, 2003). However, other definitions can also be found. Lovelock and Wirtz (2016), for example, used the notion of a "bold customer" and described her/him as someone acting in a senseless or improper way and creating problems for companies, their personnel and other customers. They emphasized that, naturally, companies must accept consumer complaints, and more importantly, they should manage them professionally. This should also be true for bold consumers, who are not welcome by service providers; however, in most cases, companies are forced to monitor and prevent this type of behaviour.

Hoffman and Bateson (2010) referred to consumer misbehaviour while discussing the causes of failure in service provision and describing problematic consumers. From their point of view, failure in proper service provision, even though potentially due to service provider shortfalls, very often depends on problematic consumers and their behaviour, such as breaching of the sales policy, customers' unwillingness to cooperate, or even verbal and physical abuse (Neuman and Baron, 1998; Aquino et al., 2001).

According to Woo and Fock (2004), the axiom that the "customer is always right" is no longer applicable, and companies often realize that the customer is, in fact, not right at all (Grandey et al., 2004). Although customer satisfaction is essential in building a long-term relationship, some customers are incapable of being completely satisfied because the cost of a
Complexity in business relations misbehaviour

3603 
$\mathrm{BFJ}$

122,11

3604

more advanced service could become unprofitable. Nevertheless, not every satisfied customer can be retained; in fact, too much attention focused on the so-called "bad customers" may pose a threat to the company's performance and existence: "good customers" should be retained as long as possible, whereas "bad ones" should be eliminated Shannahan et al., 2016).

Consumer misbehaviour has also been referred to as "abnormal consumer behaviour" by Fullerton and Punj, 1998: they define this type of behaviour as the one that breaks all generally accepted conduct norms in the market and is expected to be unacceptable by sellers and most consumers. Abnormal consumer behaviour can lead to serious material, physical, or psychological damage for the staff and other consumers Ang and Koslow, 2012; Fan et al., 2012; Kashif and Zarkada, 2015).

Moschis and Cox (1989) suggest consumer pathological behaviour as being deviant, opposite to common norms and standards in the form of customs, rules, regulations, laws and so forth. When consumer behaviour is not compliant with these norms, society perceives it as unacceptable, undesirable and dysfunctional. The defined criteria may differ in regard to their significance for society, which, for eg. expects its members to be rational consumers, although this rationality is not precisely and unequivocally defined, considering that in general, such irrationality as behaviour is capable of disturbing the functioning of the system. In fact, the commercial exchange has fundamental importance for the sound and healthy functioning of the market itself, and society expresses its expectations through rules and regulations that monitor exchange processes.

However, since the market is not uniform in regard to individual needs, values, or behaviours, the consumer may not always observe general consumption norms (e.g. smoking ban). In addition, consumer behaviour, which is not compliant with the standards perceived as norms by most consumers and which is even dysfunctional for society, does not always have to be deviant. In fact, the consumer cannot respect general food consumption habits (e.g. she/he can be a vegan) or she/he can be engaged in behaviour that is deemed dysfunctional (e.g. impulse shopping, materialistic lifestyle, or brand loyalty) because doing so may not contribute to the effective allocation of resources. Nonetheless, such types of behaviour may not be "deviant" because they may allow for individual/group customer satisfaction or even well-being (Martin et al., 2013; Dootson et al., 2016; Lee and Ahn, 2016).

According to Mitchell et al. (2009), unethical consumer behaviour should be looked upon as direct and indirect activities that also lead to consumers' or companies' financial losses and reputation damage. Vitell and Muney (1992) identified three basic factors affecting the decisionmaking process: the first factor refers to the role played by consumers (e.g. whether their behaviour is active or passive), the second factor concerns the perceived illegal character of the behaviour (dishonest and treacherous activities), and the third factor relates to the apparent significance of the associated consequences (whether a given activity can be easily spotted by others).

Reynolds and Harris (2009) define pathologies in consumer behaviour as dysfunctional and refer to situations in which the consumer consciously violates generally accepted conduct norms in consumption. By using the "dysfunctional behaviour" concept, they emphasize the intentions and infringement of norms.

With reference to the above-presented considerations, the following study on consumer misbehaviour in food markets is based on the assumption that misbehaviour concerns consumer actions that are not compliant with the generally accepted norms of market conduct and that are taken only to maximize consumers' own benefit. Simultaneously, misbehaviour exerts a negative influence both on companies/stores and on other consumers, as well as on the consumer herself/himself.

\section{Research objectives and methods}

Based on the above analysis of previous studies in the field, the adopted misbehaviour definition concerns the applicable market rules that the consumer may want to hide or distort. 
On this basis, two main research questions have arisen, with different natures, with RQ1 being more qualitative and RQ2 being more quantitative.

RQ1. "How can consumer misbehaviour in food markets be described for categorization?"

RQ2. "Can a motivation-capacity-opportunity model interpret consumer misbehaviour in food markets?."

In this respect, it was decided to carry out direct research with representatives of stores offering food (considering food markets as the most usual, common and traditional in everyday life) and having direct contact with consumers to respond to RQ1. For identifying consumers' attitudes towards the phenomenon of consumer misbehaviour in the market, a decision was made to carry out direct research among consumers to respond to RQ2.

According to the above description of the study, in the first stage, the research was conducted among representatives of grocery stores where consumers buy food, i.e., where there is direct contact between the consumer and the market and where consumer misbehaviour may occur. This research is qualitative and exploratory in nature, adopting an in-depth interview method. As recommended by Eisenhardt (1989), repeated case studies included six stores: in the literature on the subject, researchers argue that too many cases cause an increase in the cost of the study due to the need for a large number of interviews, making it difficult to collect and assimilate such large amounts of qualitative data, while more than 15 cases are too complex to manage for the study (Miles and Huberman, 1994); on the other hand, Perry (2000) postulates that this kind of research should include a minimum of $2-4$ cases and that the maximum number should be 10, 12 or 15 . Based on the above factors, it was decided to conduct research on a sample of six grocery stores operating in Poland. Interviews were conducted in January and February 2016 with representative managers of the customer service or sales departments, and the research tool was a semi-structured questionnaire (cf. Appendix 1), validated through several pilot tests before administration. The specific aim of the investigation at this stage was to identify the main types of misbehaviour in food markets, with possible reference to scale, seasonality and causes.

In the second stage, subsequently, the research concerned a sample of consumers. The research is quantitative in nature, with a nationwide perimeter (Poland). The purpose of this investigation was to determine consumer attitudes towards misbehaviour to build a potential model for decoding, interpreting and framing consumer misbehaviour in food markets. Direct research was conducted using the online survey method in 2016, and the total number of respondents was 1,395. After verification of the correctness, validity and reliability of the collected material, a final 1,200-questionnaire dataset was analysed (this round figure has been reached by excluding further responses for the purpose of providing major ease, immediateness and flexibility to the data analysis). The main part of the survey questionnaire comprised questions in the form of a Likert scale (cf. Appendix 2), validated through several pilot tests before administration.

Starting with the motivation-opportunity-ability (MOA) model by MacInnis and Jaworski (1989), question construction was fundamentally based on this three-factor (3F) model of consumer behaviour with respect to

(1) Motivation

(2) Capacity

(3) Opportunity

considering the assumption that before "deciding upon" some definite behaviour (e.g. the consumer makes a decision about purchasing food in the market), the consumer defines her/
Complexity in business relations misbehaviour

3605 
$\mathrm{BFJ}$

122,11

3606

his motivation, assesses her/his capacity and evaluates the opportunity. In the $3 \mathrm{~F}$ model, it is assumed that all the variables that determine consumer behaviour in the market may be reduced to three major determinants: with such a level of generalization, more detailed analyses of the determinants seem pointless for this research.

It should be emphasized that the three main determinants may affect (influence) one another when, for example, a low level of opportunities perceived by the consumer, or her/his insufficient capacity, cancels out the consumer's high motivation to become involved in some behaviour. In the case of insufficient motivation, the consumer, in turn, cannot be encouraged to make a purchase in the market, even despite a high level of capacity and/or opportunities (Antonides and Raaij, 2003). In this respect, it is also presumed that these assessments require some, even minimal, knowledge, intellectual and time engagement on the part of the consumer.

\section{Result interpretation and discussion}

The first phase of the study: a qualitative investigation

As an initial step in global research, some types of consumer misbehaviour in grocery stores, where consumers buy food, have been identified on the basis of in-depth interviews with representatives of grocery stores: almost surprisingly, they can detect characteristic misbehaviours among consumers with extreme ease, easily recalling countless situations. For example, thieves are most often exchanged from cheap to very expensive: cheap thieves "like" food snacking in most grocery stores, and all sellers noted that there seems to exist a decrease in products with higher prices, e.g. pistachios or expensive candies by weight. Everyone pointed out that the problem is not only the theft of this type of product but also the mess that consumers leave behind, scattering peels and other garbage throughout the store (see the following interview excerpts, after adjusting for colloquial expressions).

Petty thieves, for example, steal food for their needs, and here, the ingenuity of customers has no limits. Our favourite anecdotal story is the 'Lord', a very elegantly dressed man, in a long coat, and with a grilled chicken that was carried under his hat; hot fat was running down his face.

We have most thefts among regular, often so-called golden, customers, notoriously hiding products under palettes, e.g. a cheese palette; they will put some packages of meat between the paletteexpensive, of course. Because she/he knows that hardly anyone will check her/him because she/he waved the gold card to the cashier. In addition, if you catch her/him, she/he is outraged at the cashier (!). While she/he did not notice.

Another characteristic in consumer misbehaviour in stores is behaving uncomfortably towards employees of the store, shouting at the cashiers for various reasons such as nonworking terminals, unavailability of products in the store, or cashiers changing the cashier's tape. Other consumers are fussing about seemingly trivial matters.

Sometimes, the scenes are so bizarre, even draconian; for example, one came to the cash register, put some pasta on the tape that had been originally packed, and told me that there were two decagrams less, holding a great grudge against me. Another imposed that there were too many sausages in the packet, claiming not to pay for them.

Representatives of grocery stores indicate that the scale of the occurrence of consumer misbehaviour is very large, especially in relation to petty thieves who can "operate" several times a day. In hypermarkets, executives try to ask for such thieves to be traced, and as it turns out, it happens many times every day.

Commonly, I would not be lying if I say that every day, we see our security guards taking someone into the room. If they invite someone there, it is because there is something... We see it on different shifts, no matter the time of the day or the day of the week. In addition, what is worse, security guards 
even know which clients, so to speak, someday had something behind their ears. . .I do not believe that if someone has already done something once or has tried to sneak it, he still comes, he buys, he buys... he treats the crew like idiots who have no eyes, who do not know...

Increased theft can be observed in different seasons of the year, e.g. during holidays such as Women's Day or Teacher's Day, when the number of thefts of sweets increases, or during Christmas or Easter, when there is more traffic in stores. In addition, store representatives can specify a sort of scale of theft against individual groups of store stakeholders.

We can specify inventory differences as a percentage of turnover. On average, we statistically assume that $1 / 3$ are thefts by customers, $1 / 3$ are thefts by employees, and $1 / 3$ are thefts or mistakes by delivery staff, drivers or warehousemen. . It depends on the store, but I think $0.5 \%$ of turnover is not overestimated, it happened, and 3\%, $4 \%$ was already very pathological.

Representatives of grocery stores mostly point to the psychological conditions of consumer misbehaviour, including above all the habits, lifestyle and personality of a given consumer. Respondents most often refer to the example of petty thefts, which usually occur in food markets among people who have a habit of eating products from self-service positions during shopping or who show personality traits, a peculiar nature inclining to this type of behaviour. Some pathological behaviours are also explained, for eg. by consumers' income and their desire to make a "profit." Moreover, respondents have also pointed to the socio-cultural conditions of this type of behaviour, particularly social consent.

Regarding petty thefts, unfortunately, there is social consent for this in our country (Poland). I was touched two days ago when a customer started yelling at another customer who took a handful of pistachios and put it in his pocket. However, it only happens once a year that a client reacts to something similar to this. Rather, it is the opposite; when I try to draw attention, I encounter aggression that after all she/he only tries, that has to check.

Respondents also believe that an important element conditioning the appearance of misbehaviour is the environment of the consumer, considering family or reference groups that a given consumer can imitate and learning certain behaviours from them; hence, some people never steal, and others see no problem in it. Another condition is a favourable sales location and/or product display.

The form of product display, that it is simply self-service and therefore easy access. We are really going this way. The lower my position, the more I wanted to secure the goods because I was responsible for it. However, the position of my bosses has always been "no"; no additional goals and no additional display cases. We serve everything to the customer on a golden tray. As long as there were cash and gates in the alcohol zone, these thefts were limited. At the time when the law allowed us to endure it, we did it, and the theft of alcohol increased immediately.

Thus, from an exploratory point of view, the response to RQ1 ("How can consumer misbehaviour in food markets be described for categorization?") highlights that the most common consumer misbehaviour situations in food markets concern theft, leaving a mess behind and adopting bad behaviour towards store employees. Nonetheless, representatives of grocery stores think that there exists large-scale consumer misbehaviour, due most of all to influences on the psychological conditions of consumers, both at the individual (habits, lifestyle and personality) and collective (family or other social groups) levels, providing logical reasons for the following theoretical model construction.

\section{The second phase of the study: quantitative investigation}

For constructing a model describing consumer misbehaviour in food markets, the results of an online survey conducted among consumers have been used. First, the collected data were processed via exploratory factor analysis (EFA).
Complexity in business relations misbehaviour

3607 
$\mathrm{BFJ}$ 122,11

3608
For checking the accuracy of the selection of the factor analysis model, the Kaiser-MeyerOlkin indicator was used as a method of analysing the collected data (Gatnar and Walasiak, 2004). The value of the KMO indicator for the 24 variables under analysis is equal to 0.919 .

In addition, Bartlett's sphericity test was used. Bartlett's sphericity test verifying the hypothesis that the correlation matrix between variables unitarily rejects this judgement, with a value of 0.01 .

The approximate chi-square value is equal to 11040.911, with a degree of freedom of 276 and a level of significance of 0.000 . Therefore, it can be concluded that concerning the KMO value, the measure of sampling adequacy is evidence of the high quality of the data for factor analysis and, concerning Bartlett's sphericity test, that there are statistically significant correlations between variables, which is a premise for using factor analysis.

For determining the number of factors to be taken into consideration for further analysis, the landfill method was used: in the case under study, the phenomenon of "landfill" ambiguously indicates three or four factors, and therefore, a problem arises about which factor should be the object of selection. There are two positions in the literature: one recommends leaving as many factors as possible on the "slope," along with the one from which the "landslide" begins, while the second position recommends ignoring this factor (Lehmann et al., 1997).

Thus, the eigenvalue and the percentage of variance explaining the subsequent components have been calculated (cf. Table 1). The eigenvalue criterion sets the lowest limit for the number of factors shared in the population correlation matrix. This means that the number of factors will always be equal to or greater than the number specified by this criterion.

\begin{tabular}{|c|c|c|c|c|c|c|}
\hline \multirow[b]{3}{*}{ Component } & \multicolumn{5}{|c|}{ Total explained variance } & \\
\hline & & \multicolumn{2}{|c|}{ Initial eigenvalues } & \multicolumn{2}{|c|}{ Sums of squares of charges after rotation } & \\
\hline & Total & $\%$ Variance & $\%$ Cumulated & Total & $\%$ Variance & $\%$ Cumulated \\
\hline 1 & 7.523 & 31.345 & 31.345 & 4.474 & 18.641 & 18.641 \\
\hline 2 & 2.537 & 10.571 & 41.917 & 4.082 & 17.008 & 35.649 \\
\hline 3 & 1.641 & 6.836 & 48.753 & 3.145 & 13.104 & 48.753 \\
\hline 4 & 0.988 & 4.204 & 53.097 & & & \\
\hline 5 & 0.943 & 4.116 & 57.213 & & & \\
\hline 6 & 0.905 & 3.772 & 60.985 & & & \\
\hline 7 & 0.866 & 3.608 & 64.593 & & & \\
\hline 8 & 0.776 & 3.234 & 67.827 & & & \\
\hline 9 & 0.711 & 2.960 & 70.787 & & & \\
\hline 10 & 0.649 & 2.706 & 73.493 & & & \\
\hline 11 & 0.607 & 2.530 & 76.023 & & & \\
\hline 12 & 0.593 & 2.471 & 78.494 & & & \\
\hline 13 & 0.582 & 2.423 & 80.917 & & & \\
\hline 14 & 0.549 & 2.287 & 83.204 & & & \\
\hline 15 & 0.516 & 2.151 & 85.355 & & & \\
\hline 16 & 0.479 & 1.994 & 87.349 & & & \\
\hline 17 & 0.446 & 1.860 & 89.209 & & & \\
\hline 18 & 0.439 & 1.830 & 91.039 & & & \\
\hline 19 & 0.414 & 1.724 & 92.763 & & & \\
\hline 20 & 0.408 & 1.699 & 94.462 & & & \\
\hline 21 & 0.390 & 1.625 & 96.087 & & & \\
\hline 22 & 0.365 & 1.520 & 97.608 & & & \\
\hline 23 & 0.358 & 1.494 & 99.101 & & & \\
\hline 24 & 0.216 & 0.899 & 100.000 & & & \\
\hline
\end{tabular}

\section{Table 1.}

Identification of the principal factorial components through eigenvalues and percentages of variance. Authors' calculation 
As a result of the applied factor analysis and the adoption of the criterion of an eigenvalue greater than unity, three factors should be assumed for further analysis. Thus, assuming the allowable number of three hidden factors, a reduction of the input dataset was obtained while maintaining $48.753 \%$ of the information generated by the original set (consisting of 24 variables).

In turn, the application of the principal component method with quartimax rotation allowed for the determination of factor loads for individual variables. Table 2 indicates only significant factor loadings, rounded to not less than 0.5 in absolute value.

Thus, three multidimensional categories potentially describing the pathological behaviour of consumers in the food market have been obtained:

(1) The first category describes the variables that can lead the consumer to adopt pathological behaviour, particularly low income, search for the thrill, acceptance of the group, reluctance to feel worse than others, and desire to harm a given store or other consumers; this multidimensional category as a factor has been called "consumer motivation."

(2) The second category describes the variables highlighting that to behave pathologically, a consumer needs to spend time looking for favourable opportunities for this, have knowledge about the functioning of food markets, legal regulations and sales policies, and master the situation and be able to efficiently use modern technologies; this multidimensional category as a factor has been called "consumer capacity."

\begin{tabular}{|c|c|c|c|}
\hline \multicolumn{4}{|l|}{ Matrix of rotated components ${ }^{*}$} \\
\hline \multirow[b]{2}{*}{ Variables } & \multicolumn{3}{|c|}{ Components } \\
\hline & 1 & 2 & 3 \\
\hline Consumers misbehave when they have low income & & & \\
\hline Consumers misbehave because they are looking for a thrill & & & 0.620 \\
\hline Consumers misbehave when they want to gain group acceptance & & & 0.754 \\
\hline Consumers misbehave when they do not want to feel inferior to other consumers & & & 0.740 \\
\hline $\begin{array}{l}\text { Consumers misbehave because they want to harm an enterprise/store or other } \\
\text { consumers }\end{array}$ & & & 0598 \\
\hline $\begin{array}{l}\text { To misbehave, consumers must spend time looking for favourable opportunities } \\
\text { (e.g. situations, law gaps and so on) }\end{array}$ & & 0.563 & \\
\hline To misbehave, you need to know about the functioning of a market & & 0.784 & \\
\hline To misbehave, a good knowledge of legal regulations is necessary & & 0.849 & \\
\hline To misbehave, you need to know about sales regulations & & 0.822 & \\
\hline To misbehave, one must be calm & & 0.682 & \\
\hline $\begin{array}{l}\text { To misbehave, the consumer must be able to use modern technologies (including the } \\
\text { Internet, mobile applications and so on) }\end{array}$ & & 0.728 & \\
\hline Consumers misbehave because their surroundings behave in the same way & 0.534 & & \\
\hline Consumers misbehave when a favourable opportunity arises & 0.704 & & \\
\hline The "client our master" principle favours the appearance in consumer misbehaviour & 0.664 & & \\
\hline Unclear regulations and legal gaps favour consumer misbehaviour & 0.690 & & \\
\hline $\begin{array}{l}\text { The development of modern technologies gives consumers more opportunities to } \\
\text { misbehave }\end{array}$ & 0.575 & & \\
\hline $\begin{array}{l}\text { The speed of the emergence of new products that can meet a given need is conducive } \\
\text { to consumer misbehaviour }\end{array}$ & 0.519 & & \\
\hline High prices of products favour consumer misbehaviour & 0.666 & & \\
\hline
\end{tabular}

Method of identifying factors principal components. Method of rotation-Varimax with Kaiser normalization Note(s): * Rotation reached convergence in five interactions

Complexity in business relations misbehaviour

3609 
BFJ

122,11

3610
(3) The third category describes the variables showing what favours consumer involvement in pathological behaviour in food markets: her/his environment behaves in the same way, there are favourable opportunities for it, the "customer our master" principle uncritical adoption, unclear regulations and legal gaps, development of modern technologies, the rapid emergence of new products that may satisfy a given need, and high prices of items; this multidimensional category as a factor has been called "market opportunity."

Therefore, it can be assumed that consumer misbehaviour in food markets extracts its shape from the intervention of at least three factors: (1) the motivation of the consumer to adopt a given misbehaviour in the market, (2) her/his capacity to implement that misbehaviour and (3) the opportunity that the market creates for that consumer about possible misbehaviour (according to the $3 \mathrm{~F}$ model).

Furthermore, in the procedure, the model assuming the existence of these three constructs has been subjected to detailed analysis using confirmatory factor analysis (CFA). The adjustment of the obtained model to the data has been checked by CFA: in addition, in this model, differently from the EFA, where connections of each factor are allowed with all indicators, individual indicators are assigned to a specific construct (i.e. non-zero regression coefficients are allowed only between the given construct and the indicators assigned by the test). The quality of the measurement model has, therefore, been tested by adopting CFA.

The analysis allows for the investigation of the occurrence of correlations between factors because it can be reasonably assumed that consumers, to engage in specific misbehaviour in food markets, must be motivated, should have appropriate knowledge about markets, products and legal regulations, and thus must have the capacity to engage in such behaviour. The last indispensable factor for the occurrence of specific consumer misbehaviour is the opportunities that can emerge from markets or food stores. As a result of the analysis, it has been possible to calculate that correlations between individual constructs actually occur: the correlation index between motivation and capacity is 0.44 , between capacity and opportunity is 0.50 and between motivation and opportunity is 0.61 .

For ensuring model identification, the variance of hidden variables has been set at level 1 , i.e. they are standardized variables. This is currently the preferred solution for determining the value of 1 factor load at each of the constructs at level 1 (Browne and Mels, 1996). Both methods obtain the same standardized values of the coefficients and measures of model matching. Standardized values were estimated by adopting the highest reliability method using the AMOS program. The variables were treated as if they were interval, which gives good results with 5-point scales.

As a result of $\mathrm{CFA}$, the following values of the indicators have been obtained, measuring the quality of the adequacy between the collected data and the extracted model. Thus, the CMIN/DF (Chi-square MINimum/Degrees of Freedom, i.e., the minimum discrepancy) measure has been used first, which in the case of the analysed model is equal to 4.154, which means that it is slightly too high (it should be $<2$, although a $2-5$ value is acceptable). It refers to the convergence of the real model with the theoretical model: since the $p$-value $(p)$ is 0 , it can be assumed that these models differ; however, this measure is rarely considered a priority in the model assessment because it largely depends on the size of the sample and the potential number of latent factors.

Therefore, other measures have been used for further assessment of the model. SteigerLind's root mean square error of approximation (RMSEA) coefficient scores a high expert rating (Bollen and Long, 1993): this is a measure of how badly the model is fitted, taking into account the number of parameters that require estimation. The RMSEA value for the analysed model is 0.051 , which means that it has a satisfactory value (it should be below 0.08 ). Moreover, the upper limit of the confidence interval is CI $90=0.056$, for its actual value is also below 0.08 . 
Further measures that have been used to determine the degree of fit of the constructed model have been the goodness-of-fit index (GFI) and adjusted goodness-of-fit index (AGFI) by Joreskog and Sorbom. The values of these measures are 0.958 for GFI and 0.936 for AGFI, which are satisfactory. In addition, Bentler (1990) proposed another match indicator, the socalled normalized comparative fit index (CFI): the value for the examined model is 0.955 , which is satisfactory again. It can, therefore, be assumed that the GFI, AGFI and CFI measures have very desirable values, thus demonstrating the high quality of the model.

By considering the above analyses, it can be concluded that the model of consumer misbehaviour in food markets satisfactorily illustrates the structure of the relationships among motivation, capacity and opportunities. Table 3, in turn, presents non-standard regression coefficients and covariance values between the factors, obtained as a result of the estimation of the model by the maximum likelihood method proposed by the AMOS program: the interpretation of the coefficient values is more convenient by setting the variance of the factors at level 1 , which leads to the covariance being equal to the correlation coefficients on the diagram.

All variables that shape factors have a statistical significance of 0.01 (or even 0.001 ), and the covariance between latent variables shows statistical significance. By considering the above factors, it can be concluded that the confirmatory factor analysis shows that the examined framework about consumer misbehaviour in food markets is substantially acceptable, thus providing a positive response to RQ2 ("Can a motivation-capacityopportunity model interpret consumer misbehaviour in food markets?”).

In fact, in light of the above measures, all indicators (which have been selected on the basis of EFA) have been proven to be significantly related to the constructs that they measure. Therefore, it can be concluded that consumer misbehaviour in food markets will occur most likely if the consumer is motivated, has the capacity to engage in this behaviour, and at the same time, meets appropriate market opportunities.

Moreover, considering some concerns emerging from statistical reliability analyses, this model cannot be considered perfectly suited. For example, it is worth emphasizing that as

\begin{tabular}{|c|c|c|c|c|c|c|}
\hline \multicolumn{3}{|l|}{ Factors } & \multirow{2}{*}{$\frac{\text { Estimation }}{0.762}$} & \multirow{2}{*}{$\frac{\text { Standard error }}{0.062}$} & \multirow{2}{*}{$\frac{\text { Critical ratio }}{12.215}$} & \multirow{2}{*}{$\frac{\text { Probability value }}{0.000}$} \\
\hline Q_1_2 & $\rightarrow$ & Motivation & & & & \\
\hline Q11_3 & $\rightarrow$ & Motivation & 0.936 & 0.063 & 14.786 & 0.000 \\
\hline Q_1_5 & $\rightarrow$ & Motivation & 0.881 & 0.050 & 17.482 & 0.000 \\
\hline Q11_6 & $\rightarrow$ & Motivation & 1.000 & - & - & - \\
\hline Q11_8 & $\rightarrow$ & Motivation & 0.931 & 0.066 & 14.121 & 0.000 \\
\hline Q22_1 & $\rightarrow$ & Capacity & 0.711 & 0.041 & 17.458 & 0.000 \\
\hline Q_2_3 & $\rightarrow$ & Capacity & 0.934 & 0.037 & 25.228 & 0.000 \\
\hline Q_2_4 & $\rightarrow$ & Capacity & 1.000 & - & - & - \\
\hline Q_2_5 & $\rightarrow$ & Capacity & 0.938 & 0.027 & 34.438 & 0.000 \\
\hline Q22_7 & $\rightarrow$ & Capacity & 0.748 & 0.039 & 19.334 & 0.000 \\
\hline Q_2_8 & $\rightarrow$ & Capacity & 0.757 & 0.037 & 20.592 & 0.000 \\
\hline Q_3_2 & $\rightarrow$ & Opportunity & 0.762 & 0.054 & 14.202 & 0.000 \\
\hline Q_3_3 & $\rightarrow$ & Opportunity & 0.866 & 0.053 & 16.285 & 0.000 \\
\hline Q_3_4 & $\rightarrow$ & Opportunity & 0.864 & 0.058 & 14.952 & 0.000 \\
\hline Q_3_5 & $\rightarrow$ & Opportunity & 1.021 & 0.054 & 18.904 & 0.000 \\
\hline Q_3_6 & $\rightarrow$ & Opportunity & 0.993 & 0.049 & 20.272 & 0.000 \\
\hline Q_3_7 & $\rightarrow$ & Opportunity & 1.000 & - & - & - \\
\hline Q_3_8 & $\rightarrow$ & Opportunity & 0.953 & 0.048 & 19.753 & 0.000 \\
\hline Motivation & $\leftrightarrow$ & Capacity & 0.477 & 0.047 & 10.074 & 0.000 \\
\hline Motivation & $\leftrightarrow$ & Opportunity & 0.487 & 0.042 & 11.542 & 0.000 \\
\hline Capacity & $\leftrightarrow$ & Opportunity & 0.584 & 0.049 & 11.855 & 0.000 \\
\hline
\end{tabular}

Complexity in business relations misbehaviour

3611
Table 3.
Confirmatory factor analysis for constructs determining consumer misbehaviour on the market (non-standard parameters). Authors' calculation 
BFJ

122,11

shown by EFA calculations, the consumer's capacity and market opportunities are the most relevant factors, while consumer motivation is the least important component of the so-constructed model.

\section{Scientific and managerial implications}

The so-constructed three-factor model for interpreting consumer misbehaviour in food markets and its potential impact on a company's business model adjustment/amendment have many advantages, as well as applications. In particular, this framework seems capable of executing important theoretical and practical functions.

From a scientific point of view, this research can greatly contribute to the development of some specific marketing theories, especially those focusing on consumer behaviour, retail mix and customer relationship management. In addition, the model can generate significant support in understanding complex relations among consumers, food producers and food stores, thus contributing to the advancement of partnership marketing theories. In addition, it permits us to better understand the impact of the observed phenomenon on supply chain management, showing a strong connection with the "input-output" model (Ferrero, 1968) and analysing some specific marketing theories through an interdisciplinary approach for understanding the potential relationships between consumer behaviour (or, in this case, misbehaviour) and the company business model. In the assessment of its cognitive impact, it is useful also to highlight the framework simplicity, as it demonstrates clearly that there exist different aspects of consumer misbehaviour, which are able to be assigned to three understandable multidimensional categories-factors-that can exert influence and interaction. The model is helpful not only in explaining how and why consumer misbehaviour appears in food markets but also in predicting similar situations under the influence of some specific factors; nonetheless, the framework shows basic logic by virtue of its internal consistency, which has been confirmed empirically.

From a managerial point of view, the consumer misbehaviour model may be widely applied in operation governance and execution on behalf of food producers and sellers; in fact, it allows for the understandable explanation of consumer market misbehaviour, with immediate interventions to adopt about the market opportunities factor above all. Therefore, the decision-making process of entrepreneurs and managers may favour stricter sales strategies and more ample supply chain management.

Nevertheless, possessing knowledge about consumers and their behaviour is indispensable not only for the development of any marketing programme, including marketing strategies of food producers and sellers but also for the elaboration of methods for preventing and counteracting different consumer misbehaviours in food markets. Similar to careful governmental policies, these activities are meant to serve not only the other consumers but also the interests and profits of food producers and sellers.

\section{Research limitations and future directions}

The study shows some limitations, which, however, can be turned into advantages for future research. The key limitation of the research concerns a geographical shortfall since it was conducted only in one country, also characterized by strong economic impetus in recent years, with all the potential considerations that may arise; in fact, consumer misbehaviour may differ not only if adopting a cross-cultural perspective but also if considering possible differences in well-developed countries, as well as in poor, less-developed countries.

Therefore, it is believed that focusing on different markets, analysing the phenomenon in different countries, and sampling different consumer segments will contribute to a better understanding of consumer misbehaviour and related attitudes towards sustainable 
consumption. In doing so, further desirable improvement of the research could also involve the application of the experimental methods, particularly when based on observation techniques to be operated in the food markets, with obvious respect for all the provided limitations about the privacy of every involved person.

Finally, another limit could concern the "food" nature of the markets under analysis in this study: in fact, one could imagine that for other sectors, the situation may change. Naturally, it could happen, but in truth, the $3 \mathrm{~F}$ model seems quite appropriate for other good and/or services, for which, most likely, it could be possible that other factors in addition to market opportunity in the food sector may influence potential consumer misbehaviour (for example, consumer capability in the case of services).

\section{Conclusions}

The qualitative part of the research has shown that the most common misbehaviour adopted by consumers in food markets is the theft of foodstuff; in addition, consumers often leave a mess behind, scattering peels and other trash throughout the store. Another characteristic pathology in consumer behaviour in grocery stores is unpleasant, aggressive and vulgar behaviour towards store employees.

More generally, representatives of grocery stores have highlighted that the scale of the occurrence of pathological consumer behaviour is very large, mostly pointing to psychological conditions of pathological behaviour among consumers, including above all the habits, lifestyle and personality of a given consumer, as well as the influence of the family or various social groups. A subsequent investigation, starting from this emerging evidence, concerned the construction of a theoretical model for interpreting consumer misbehaviour in food markets.

Within the "input-output" model (Ferrero, 1968), consumer misbehaviour may be considered an input, generating a restriction or an opportunity. In fact, it could represent a restriction when considering the interference of negative actions on behalf of the consumer on the planned sales activity, but at the same time, it could represent an opportunity to reinforce the overall company-consumer relationship, which could become more trustworthy when inspired by positive countermeasures to potential negative actions. Thus, adopting the "input-output" model, the management of the contextual complexity in different business relationships, such as consumer misbehaviour, can create new utility in the overall business functioning.

The quantitative part of the research, conducted among consumers, has shown that consumer misbehaviour in food markets can be determined fundamentally on the basis of three factors (3F model): motivation, capacity, and opportunity, which most likely appear simultaneously for the misbehaviour to occur. In particular, of the three factors, the opportunity seems to be the most significant for consumer misbehaviour in food markets, even more so when theoretically and practically contextualized into the general "inputoutput" model.

These results can be transferred into useful applications for several reasons, from adopting preventive measures to exploiting consumption experiences, particularly for food markets, but also for the markets of other products/services. Customer knowledge management, when correctly adopted and executed, is constantly an essential tool for establishing, developing, enhancing and protecting profitable relationships between firms and consumers, also favouring the understanding and governing of overall supply chain management according to the "input-output" model (Ferrero, 1968).

\section{Notes}

Authors' contribution The article is the result of the common reflection of all the authors. In the editing phase, the "Introduction", "Scientific and managerial implications", "Research limitations and future 
$\mathrm{BFJ}$ 122,11 directions", and "Conclusions" sections were written by Alberto Mazzoleni; the "Consumer misbehaviour-Theoretical background" and "Research objectives and methods" sections were written by Giuseppe Festa; the "The second phase of the study: quantitative investigation" section was written by Slawomir Smyczek; and the "The first phase of the study: qualitative investigation" section was written by Matteo Rossi.

\section{References}

Ang, L. and Koslow, S. (2012), "Customers behaving badly!", in Barnes, A. and Taksa, L. (Eds), Rethinking Misbehavior and Resistance in Organizations (Advances in Industrial and Labor Relations), Emerald, Bingley, Vol. 19, pp. 181-207.

Aquino, K., Tripp, T. and Bies, R. (2001), "How employees respond to interpersonal offense: the effects of blame attribution, offender status, and victim status on revenge and reconciliation in the workplace", Journal of Applied Psychology, Vol. 86 No. 1, pp. 52-59.

Antonides, G. and van Raaij, W. (2003), Consumer Behaviour. European Perspective, Wiley, New York, NY.

Bentler, P.M. (1990), "Comparative fit indexes in structural models", Psychological Bulletin, Vol. 107 No. 2, pp. 238-246.

Bollen, K.A. and Long, J.S. (1993), Testing Structural Equation Models, Sage, Newbury Park, CA.

Bozzolan, S. (2001), Bilancio e valore, McGraw-Hill, Milan.

Browne, M.W. and Mels, G. (1996), Path Analysis: RAMONA. SYSTAT 6.0 for Windows: Statistics, SPSS, Chicago, IL.

Coda, V. (1988), L'orientamento Strategico Dell'impresa, Utet, Turin.

Dootson, P., Johnston, K.A., Beatson, A. and Lings, I. (2016), "Where do consumers draw the line? Factors informing perceptions and justifications of deviant consumer behaviour", Journal of Marketing Management, Vol. 32 Nos 7-8, pp. 750-776.

Durkheim, E. (2000), Zasady Metody Socjologicznej/the Principles of the Sociological Method, PWN, Warsaw.

Eisenhardt, K. (1989), "Building theories from case study research", The Academy of Management Review, Vol. 14 No. 4, pp. 532-550.

Fan, G., Ma, Q., Liu, R. and Hao, J. (2012), "Why customers behave badly? The review of antecedent research on customer misbehavior", Proceedings of the International Joint Conference on Service Sciences, Shanghai, 24-26 May, pp. 185-190.

Ferrero, G. (1967), Le Determinazioni Economico-Quantitative D’azienda, Giuffré, Milan.

Ferrero, G. (1968), Istituzioni di economia d'azienda, Giuffré, Milan.

Ferrero, G. (1987), Impresa e management, Giuffré, Milano.

Fullerton, R. and Punj, G. (1998), "The unintended consequences of the culture of consumption: an historical-theoretical analysis of consumer misbehaviour", Consumption Markets and Culture, Vol. 1 No. 4, pp. 393-423.

Gatnar, E. and Walesiak, M. (2004), Metody Statystycznej - Analizy Wielowymiarowej W Badaniach Marketingowych/Statistical Methods - Multidimensional Analysis in Marketing Research, Wroclaw University of Economics Press, Wroclaw.

Giacosa, E. (2012), Mergers and Acquisitions (M\&As) in the Luxury Business, McGraw-Hill, Milan.

Giunta, F. (1993), La creazione di nuove imprese, Cedam, Padua, 1993.

Grandey, A.A., Dickter, D.N. and Sin, H.P. (2004), "The customer is not always right: customer aggression and emotion regulation of service employees", Journal of Organizational Behaviour, Vol. 25 No. 3, pp. 397-418.

Ho, C.S.F. (2020), "Exchange rate behaviour of east European transitional economies", International Journal of Banking and Finance, Vol. 6 No. 2, pp. 95-109. 
Hoffman, K. and Bateson, J. (2010), Services Marketing: Concepts, Strategies, and Cases, South-Western Cengage Learning, Mason, $\mathrm{OH}$.

Kashif, M. and Zarkada, A. (2015), "Value co-destruction between customers and frontline employees: a social system perspective", International Journal of Bank Marketing, Vol. 33 No. 6, pp. 672-691.

Lehmann, D.R., Gupta, S. and Steckel, J.H. (1997), Marketing Research, Addison-Wesley, Boston, MA.

Lovelock, C. and Wirtz, J. (2016), Services Marketing: People, Technology, Strategy, World Scientific Publishing, Hackensack, NJ.

Lee, M.S.W. and Ahn, C.S.Y. (2016), "Anti-consumption, materialism, and consumer well-being”, The Journal of Consumer Affairs, Vol. 50 No. 1, pp. 18-47.

MacInnis, D.J. and Jaworski, B.J. (1989), "Information processing from advertisements: toward an integrative framework", Journal of Marketing, Vol. 53 No. 4, pp. 1-23.

Martin, I.M., Kamins, M.A., Pirouz, D.M., Davis, S.W., Haws, K.L., Mirabito, A.M., Mukherjee, S., Rapp, J.M. and Grover, A. (2013), "On the road to addiction: the facilitative and preventive roles of marketing cues", Journal of Business Research, Vol. 66 No. 8, pp. 1219-1226.

Mazzoleni, A. (2012), La comunicazione economico-finanziaria delle imprese con il sistema bancario, McGraw-Hill, Milan.

Miles, M.B. and Huberman, A.M. (1994), Qualitive Data Analysis - an Expanded Sourcebook, Sage, Newbury Park, CA.

Mitchell, V.W., Balabanis, G., Schlegelmilch, B.B. and Cornwell, T.B. (2009), "Measuring unethical consumer behaviour across four countries", Journal of Business Ethics, Vol. 88 No. 2, pp. 395-412.

Moschis, G.P. and Cox, D. (1989), "Deviant consumer behaviour", Advances in Consumer Research, Vol. 16 No. 1, pp. $732-737$.

Neuman, J.H. and Baron, R.A. (1998), "Workplace violence and workplace aggression: evidence concerning specific forms, potential causes, and preferred targets", Journal of Management, Vol. 24 No. 3, pp. 391-419.

Paolini, A. (1997), "Il monitoraggio ambientale", in Marchi, L., Paolini, A. and Quagli, A. (Eds), Strumenti di analisi gestionale, Giappichelli, Turin.

Pavan, A. and Modica, P. (2014), Valori etici, valore economico e controlli interni nelle aziende, in Laghi, E. and Zanda, G. (Eds), Scritti in onore di Pellegrino Capaldo, Egea, Milan.

Pavan, A. and Modica, P. (2016), "L'etica nella teoria e negli strumenti aziendali", Rivista italiana di ragioneria e di Economia aziendale, Vol. 66 No. 1, pp. 343-351.

Perry, C. (2000), "Case research in marketing”, The Marketing Review, Vol. 1 No. 3, pp. 303-323.

Pollifroni, M. (2017), L’Etica Aziendale nei Processi di Globalizzazione dei Mercati. Paradigmi, Determinanti, Valutazioni, Giappichelli, Turin.

Pospiszył, I. (2008), Patologie Spoteczne, Resocjalizacja/Social Pathologies, Resocialisation, PWN, Warsaw.

Reynolds, K.L. and Harris, L.C. (2009), "Dysfunctional customer behaviour severity: an empirical examination”, Journal of Retailing, Vol. 85 No. 3, pp. 321-335.

Saita, M. (2005), I fondamentali dell'economia e strategia aziendale, Giuffré, Milan.

Shannahan, R.J., Shannahan, K.L.J., Bush, A.J. and Moncrief, W.C. (2016), "Taking the good with the bad-customer type as a segmentation criterion and differential influencer of sales performance", Journal of Marketing Theory and Practice, Vol. 24 No. 3, pp. 283-305.

Siemaszko, A. (1993), Granice Tolerancii. O Teoriach Zachowan Dewiacyjnych / the Limits of Tolerance. Theories of Deviant Behaviour, PWN, Warsaw, Poland.

Sztompka, P. (1979), Sociological Dilemmas: Toward a Dialectic Paradigm, Academic Press, New York, NY.

Tiscini, R. (2014), La Strategia Aziendale, Economia aziendale, Egea, Milan, Italy.
Complexity in business relations misbehaviour

3615 
Vitell, S.J. (2003), "Consumer ethics research: review, synthesis and suggestions for the future”, Journal of Business Ethics, Vol. 42 Nos 1/2, pp. 33-47.

Vitell, S.J. and Muney, J. (1992), "Consumer ethics: an empirical investigation of factors influencing ethical judgments of the final consumer", Journal of Business Ethics, Vol. 11 No. 8, pp. 585-92.

Woo, K.S. and Fock, H.K. (2004), "Retaining and divesting customers: an exploratory study of right customers, "at-risk" right customers, and wrong customers", Journal of Services Marketing, Vol. 18 No. 3, pp. 187-197.

\section{Appendix 1}

\section{IN-DEPTH INTERVIEW QUESTIONNAIRE}

1.

How do you understand the expression 'consumer misbehaviour'? What do you associate with this expression?

2.

What consumer behaviour do you consider a misbehaviour? Can you name examples of consumer misbehaviour that you have encountered in your industry? Do you use internal expressions in your industry for consumer misbehaviour?

3.

How often do you encounter consumer misbehaviour? For example, is there any seasonality that increases the incidence of misbehaviour among consumers? What is the scale of misbehaviour among consumers in your industry?

4.

Could you list the reasons for the occurrence of consumer misbehaviour in your industry? What can influence the creation/generation of this type of behaviour inside your company? Industry? Environment?

5.

Could you present the profile/characteristics of the misbehaving consumer? Are there any typical features of misbehaving people? Does anything differentiate this type of consumer?

6.

Can you name the (positive and negative) consequences of the above-mentioned consumer misbehaviours in your industry (for the consumer, for other consumers, for the company, for other entities)?

7. Which of the above-mentioned consumer misbehaviours do you consider to be committed by consumers consciously? Which ones unconsciously?

8.

What is the level of social acceptance for the above-mentioned consumer misbehaviour?

9.

How does your company react to consumer misbehaviour? Does your company have a response model or strategy for dealing with such behaviour?

10.

Have you been trained in any way on how to deal with bad consumer behaviour? If so, how?

11.

Do you have your own way of dealing with a misbehaving consumer?

12.

Do you have any suggestion or observation on how to eliminate consumer misbehaviour in your industry?

Thank you for participating in this research. 


\section{Appendix 2}

1.

Do you know the expression 'consumer misbehaviour'?

Yes

No

2.

Which consumer behaviour in the market do you think or would you consider to be a misbehaviour (please mark a maximum of 3 answers)

a. unknowingly committed bad behaviour

b. behaviour that has a negative effect on the consumer

c. behaviour that has a negative effect on other consumers

d. behaviour that has a negative effect on the enterprise

e. behaviour that is clever

f. behaviour to achieve the expected benefits

g. behaviour that goes beyond social norms

h. behaviour related to breaking the law

i. deliberately committing bad behaviour

j. other (what?):

3.

What is your attitude towards consumer misbehaviour?

\begin{tabular}{|c|c|c|c|c|c|c|c|}
\hline \multirow[b]{2}{*}{ Specification } & $\begin{array}{l}\text { I totally } \\
\text { disagree }\end{array}$ & $\begin{array}{c}\text { I do not } \\
\text { agree }\end{array}$ & $\begin{array}{c}\text { Rather } \\
\text { disagree }\end{array}$ & $\begin{array}{l}\text { Hard } \\
\text { to say }\end{array}$ & $\begin{array}{c}\text { I rather } \\
\text { agree }\end{array}$ & $\begin{array}{c}\text { I } \\
\text { agree }\end{array}$ & $\begin{array}{c}\text { I totally } \\
\text { agree }\end{array}$ \\
\hline & 1 & 2 & 3 & 4 & 5 & 6 & 7 \\
\hline \multicolumn{8}{|l|}{$\begin{array}{l}\text { a. Misbehaviour of } \\
\text { consumers is acceptable } \\
\text { if it does not harm other } \\
\text { consumers }\end{array}$} \\
\hline \multicolumn{8}{|l|}{$\begin{array}{l}\text { b. Misbehaviour of } \\
\text { consumers is unac- } \\
\text { ceptable because it } \\
\text { destroys businesses }\end{array}$} \\
\hline \multicolumn{8}{|l|}{$\begin{array}{l}\text { c. Misbehaviour of } \\
\text { consumers harms them }\end{array}$} \\
\hline \multicolumn{8}{|l|}{$\begin{array}{l}\text { d. Misbehaviour of } \\
\text { consumers is acceptable } \\
\text { to me }\end{array}$} \\
\hline \multicolumn{8}{|l|}{$\begin{array}{l}\text { e. I believe that there } \\
\text { can be no tolerance for } \\
\text { any misbehaviour of } \\
\text { consumers }\end{array}$} \\
\hline $\begin{array}{l}\text { f. I can accept misbe- } \\
\text { haviour of consumers in } \\
\text { justified cases }\end{array}$ & & & & & & & \\
\hline
\end{tabular}

4.

In what places do you most often encounter consumer misbehaviour?

\begin{tabular}{|l|l|l|l|l|}
\hline \multicolumn{1}{|c|}{ Place } & Never & Rarely & Often & Very often \\
\hline a. Medical outlets & & & & \\
\hline b. Public transport & & & & \\
\hline c. Banks & & & & \\
\hline d. Insurance outlets & & & & \\
\hline e. Srocery stores & & & & \\
\hline f. Discount stores & & & & \\
\hline g. Supermarkets & & & \\
\hline
\end{tabular}


$\mathrm{BFJ}$

122,11

\section{8}

\begin{tabular}{|l|l|l|l|l|}
\hline h. On-line stores & & & & \\
\hline i. Hotels & & & & \\
\hline j. Hairdresser saloons & & & & \\
\hline k. Universities & & & & \\
\hline 1. Others & & & & \\
\hline
\end{tabular}

5.

How do you think consumers most often react to the misbehaviour of other consumers?

\begin{tabular}{|l|c|c|c|c|c|c|c|}
\hline \multirow{2}{*}{ Specification } & $\begin{array}{c}\text { I totally } \\
\text { disagree }\end{array}$ & $\begin{array}{c}\text { I do not } \\
\text { agree }\end{array}$ & $\begin{array}{c}\text { Rather } \\
\text { disagree }\end{array}$ & $\begin{array}{c}\text { Hard } \\
\text { to say }\end{array}$ & $\begin{array}{c}\text { I rather } \\
\text { agree }\end{array}$ & $\begin{array}{c}\text { I } \\
\text { agree }\end{array}$ & $\begin{array}{c}\text { I totally } \\
\text { agree }\end{array}$ \\
\cline { 2 - 7 } & 1 & 2 & 3 & 4 & 5 & 6 & 7 \\
\hline $\begin{array}{l}\text { a. Directly admonish } \\
\text { consumers who are } \\
\text { misbehaving }\end{array}$ & & & & & & & \\
\hline $\begin{array}{l}\text { b. Report misbehaviour } \\
\text { of consumers to security } \\
\text { or other employees }\end{array}$ & & & & & & & \\
\hline $\begin{array}{l}\text { c. They do not pay } \\
\text { attention to misbehaviour } \\
\text { of consumers, pass } \\
\text { indifferently to these } \\
\text { behaviours }\end{array}$ & & & & & & & \\
\hline
\end{tabular}

6.

Below, there are opinions on consumer misbehaviour. Please specify the extent to which you agree with these opinions.

\begin{tabular}{|c|c|c|c|c|c|c|c|}
\hline \multirow[b]{2}{*}{ Specification } & $\begin{array}{l}\begin{array}{l}\text { I totally } \\
\text { disagree }\end{array} \\
\end{array}$ & $\begin{array}{c}\begin{array}{c}\text { I do not } \\
\text { agree }\end{array} \\
\end{array}$ & $\begin{array}{c}\text { Rather } \\
\text { disagree }\end{array}$ & $\begin{array}{l}\text { Hard } \\
\text { to say }\end{array}$ & $\begin{array}{c}\begin{array}{c}\text { I rather } \\
\text { agree }\end{array} \\
\end{array}$ & $\begin{array}{c}\text { I } \\
\text { agree }\end{array}$ & $\begin{array}{c}\text { I totally } \\
\text { agree }\end{array}$ \\
\hline & 1 & 2 & 3 & 4 & 5 & 6 & 7 \\
\hline \multicolumn{8}{|l|}{$\begin{array}{l}\text { 1. Consumers misbehave } \\
\text { to achieve greater } \\
\text { profit at lower costs }\end{array}$} \\
\hline \multicolumn{8}{|l|}{$\begin{array}{l}\text { 2. Consumers misbehave } \\
\text { when they have } \\
\text { low income }\end{array}$} \\
\hline \multicolumn{8}{|l|}{$\begin{array}{l}\text { 3. Consumers misbehave } \\
\text { because they are } \\
\text { looking for a thrill }\end{array}$} \\
\hline \multicolumn{8}{|l|}{$\begin{array}{l}\text { 4. Consumers misbehave } \\
\text { when they are not } \\
\text { satisfied with purchased } \\
\text { products }\end{array}$} \\
\hline \multicolumn{8}{|l|}{$\begin{array}{l}\text { 5. Consumers misbehave } \\
\text { when they want to } \\
\text { gain group acceptance }\end{array}$} \\
\hline \multicolumn{8}{|l|}{$\begin{array}{l}\text { 6. Consumers misbehave } \\
\text { when they do not } \\
\text { want to feel inferior to } \\
\text { other consumers }\end{array}$} \\
\hline \multicolumn{8}{|l|}{$\begin{array}{l}\text { 7. Consumers misbehave } \\
\text { because the media } \\
\text { creates a lot of new } \\
\text { needs, which the } \\
\text { consumer has difficulties } \\
\text { to satisfy in } \\
\text { legal/traditional way }\end{array}$} \\
\hline $\begin{array}{l}\text { 8. Consumers misbehave } \\
\text { because they want } \\
\text { to harm an } \\
\text { enterprise/store or other } \\
\text { consumers }\end{array}$ & & & & & & & \\
\hline
\end{tabular}




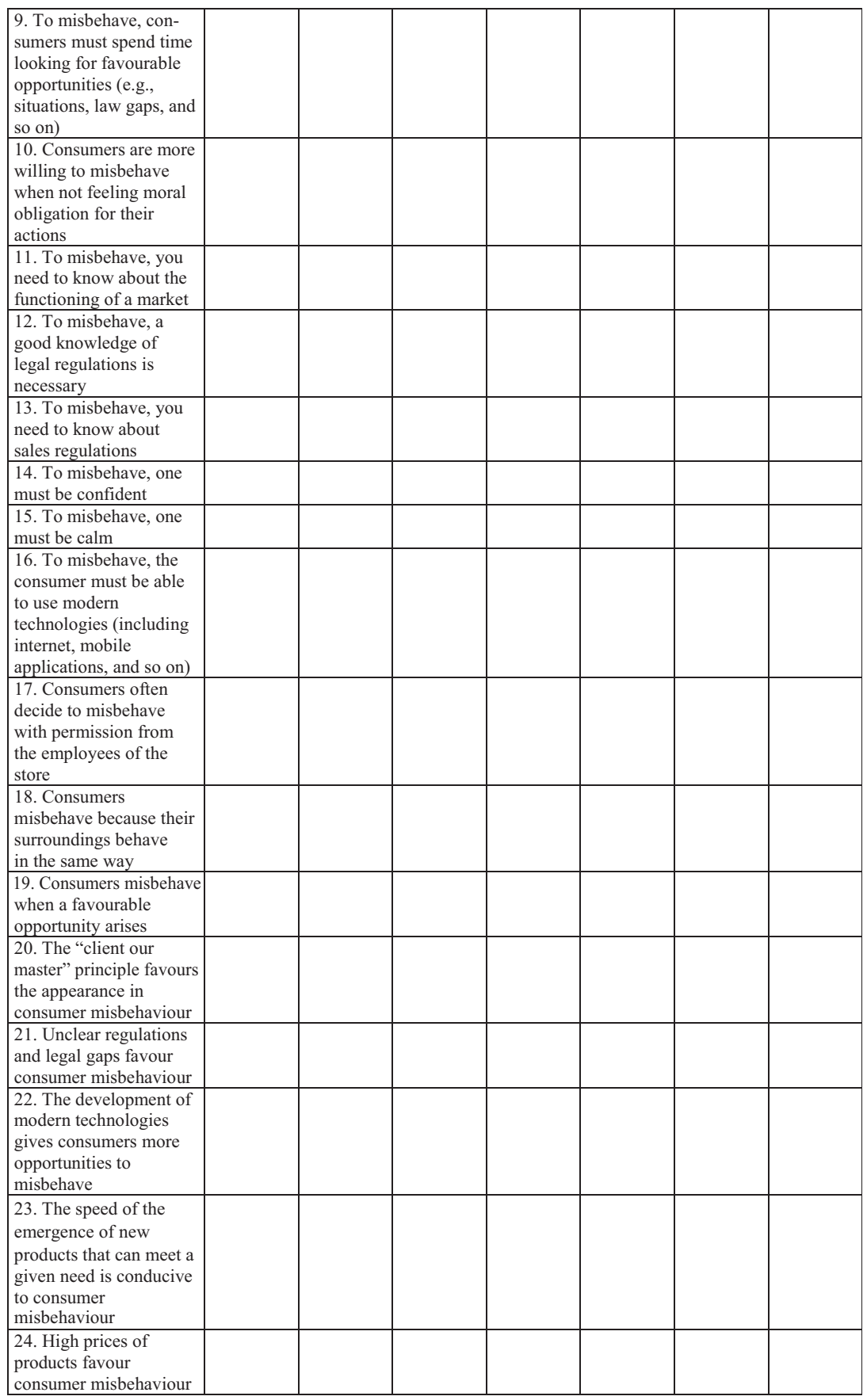

\section{Complexity in business relations misbehaviour} 3619 
BFJ

122,11

3620
7.

Gender

Female

Male

8.

Age

a. 25 years and younger

b. 26-34 years

c. 35-44 years

d. 45-54 years

e. 55-64 years

f. 65 years and older

9.

Education

a. primary

b. vocational

c. secondary

d. higher

10.

Occupation

a. physical worker

b. sales representative

c. white-collar worker (office worker)

d. teacher

e. middle manager

f. manager

g. own business

h. liberal profession (e.g., doctor, artist, lawyer, and so on)

i. pensioner

j. student

k. other (what?):

11.

Household size

a. single

b. 2 persons

c. 3 persons

d. 4 persons

e. 5 and more persons

12.

The amount of your average monthly net income ("on hand") (1 PLN = approximately 0.23 EUR)

a. below 501

b. $0,501-1,000 \quad$ PLN

c. $1,001-2,000 \quad$ PLN

d. $2,001-4,000 \quad$ PLN

e. $4,001-6,000 \quad$ PLN

f. $6,001-10,000$ PLN

g. over 10,000 PLN

13.

How do you assess your economic situation?

a. very bad

b. bad

c. average

d. good

e. very good

14.

Place of residence

a. village

b. town of up to 20,000 people

c. city with 020,000 to 100,000 people

d. city with over 100,000 people

Thank you for participating in this research. 


\section{About the authors}

Sławomir Smyczek is a Full Professor at the University of Economics in Katowice (Poland) where he earned his Ph.D. In 2010, the Polish Prime Minister awarded his habilitation thesis as the best in the field of economy. Prof. Smyczek has written and published over 200 articles and papers about consumer behaviour, behavioural finance and international marketing, and is also author and co-author of several monographs. Prof. Smyczek teaches graduate and postgraduate courses in consumer behaviour and marketing at different universities around the world. He also serves as a consultant for institutions and enterprises involved in international business.

Giuseppe Festa is an Assistant Professor of Management at the Department of Economics and Statistics of the University of Salerno, Italy. He holds a PhD in Economics and Management of Public Organisations from the University of Salerno, where he is the Scientific Director of the Postgraduate course on "Wine Business" and the Vice-Director of the Second Level Master on "Management of Healthcare Organisations - Daosan." He is also the Chairman of the Euromed Research Interest Committee on Wine Business. His research interests focus mainly on wine business, information systems and healthcare management. Giuseppe Festa is the corresponding author and can be contacted at: gfesta@unisa.it

Matteo Rossi received the Ph.D. degree in Management from the University of Sannio, Benevento, Italy. He is currently an Associate Professor of Corporate Finance at the University of Sannio, Benevento, Italy. He is also an Adjunct Professor of Advanced Corporate Finance at LUISS, Rome, Italy and Research Fellow at the Wyższa Szkoła Bankowa w Poznaniu-WSB University in Poznan, Poland. Dr. Rossi is the Editor-in-Chief for the International Journal of Managerial and Financial Accounting.

Alberto Mazzoleni is an Associate Professor of Business Administration at the University of Brescia (Italy), where he graduated in Business Administration. His main areas of research include business crisis, financial communication, business information systems and family business. He is the Scientific Director of the "Observatory on business crisis and rebalancing" at the Department of "Economics and Management" of the University of Brescia (Italy).
Complexity in business relations misbehaviour

3621

For instructions on how to order reprints of this article, please visit our website:

www.emeraldgrouppublishing.com/licensing/reprints.htm

Or contact us for further details: permissions@emeraldinsight.com 